\title{
Peran Globalisasi di Balik Munculnya Tantangan Baru Bagi Diplomasi di Era Kontemporer
}

\author{
Rizki Rahmadini Nurika* \\ rr_nurika@yahoo.com
}

\begin{abstract}
Abstrak
Globalisasi telah memberikan pengaruh yang signifikan pada kajian hubungan internasional. Salah satunya adalah ketika globalisasi memperluas cara bagaimana diplomasi itu dilakukan. Diplomasi tidak hanya dipandang sebagai agenda resmi yang di dalamnya hanya terdapat negara yang berperan sebagai satu-satunya aktor. Lebih dari itu, kini diplomasi dapat dilakukan oleh aktor bukan negara pada agenda resmi maupun tak resmi. Diplomasi juga dibekali dengan penyebaran isu-isu baru. Seiring dengan arus globalisasi, isu-isu hubungan internasional pun kini turut berkembang dan meluas sebagai dampak dari fenomena menyempitnya ruang dan waktu. Kondisi yang demikian ini lah yang kini menjadi karakteristik diplomasi di era kontemporer, yang membuat diplomasi tertantang untuk mempertahankan eksistensinya. Penelitian ini didesain untuk mengungkap logika tentang bagaimana globalisasi memicu munculnya tantangan baru bagi diplomasi. Metode yang digunakan untuk menjawab pertanyaan tersebut adalah penelitian kualitatif dengan menggunakan data sekunder. Hasil penelitian menunjukkan bahwa tantangan baru bagi diplomasi muncul ketika globalisasi mengubah sifat alamiah dari diplomasi itu sendiri.
\end{abstract}

Kata Kunci: Diplomasi, Globalisasi, Tantangan

\begin{abstract}
Globalization has given its significance influences on the study of international relations. One of them is when it has expanded the way diplomacy is performed. Diplomacy is no longer perceived only on a formal agenda in which state acts as the only one actor. Far beyond that, now diplomacy can be conducted by non-state actor both in formal and informal agenda. Diplomacy is also equipped by the spread of new issues. In line with the flow of globalization, international relations issues have developed and broadened rapidly as well as the narrowing space and time phenomena happened. Here, those given circumstances are now perceived as the characteristics of diplomacy in this contemporary era, by which diplomacy is challenged to maintain its existence. This research is designed to reveal the logic for how globalization triggers the emergence of new challenges for diplomacy. Method used to answer such question is qualitative research by using secondary data. The finding shows that new challenges for diplomacy come when globalization changes the nature of diplomacy itself.
\end{abstract}

Key Words: Challenge, Diplomacy, Globalization

\section{Pendahuluan}

Pasca berakhirnya Perang Dingin, kajian hubungan internasional dihadapkan pada tatanan dunia yang baru. Hubungan internasional kini tidak lagi merujuk pada ketegangan global sebagai dampak dari adanya struktur bi-polar yang

\footnotetext{
* Korespondensi: Departemen Hubungan Internasional, Universitas Islam Negeri Sunan Ampel, Jl. Raya Prajurit Kulon no.45 Kota Mojokerto.
} 
membagi negara-negara di dunia menjadi dua kelompok besar yaitu blok Barat dan blok Timur. Bubarnya imperium eksternal Uni Soviet di Eropa Timur yang kemudian diikuti oleh kehancuran Uni Soviet itu sendiri telah menghapuskan struktur bi-polar yang telah mendominasi hubungan internasional selama lebih dari setengah abad.

Tatanan baru yang dimulai ketika Perang Dingin usai tersebut menjadi penanda akan terciptanya era baru yang disebut-sebut sebagai era kontemporer, yaitu era di tahun-tahun terakhir sampai sekarang yang memfokuskan pada berbagai hal yang berkembang hingga saat ini. Era kontemporer ini identik dengan pengaplikasian ilmu dan teknologi dalam berbagai sektor kehidupan manusia yang berkembang dengan sangat pesat. Namun, hal paling utama yang menjadi pemicu terciptanya era kontemporer ini sejatinya adalah modern globalization.

Meskipun belum ada definisi yang pasti tentang apa itu globalisasi, tetapi secara umum dapat dikatakan bahwa globalisasi ini seringkali digambarkan sebagai situasi ketika ruang dan waktu terasa semakin menyempit. Fenomena tersebut dapat dirasakan dari adanya peningkatan interaksi antar masyarakat dunia, yaitu ketika masyarakat di berbagai belahan dunia saling terhubung satu sama lain seakan tak terhambat oleh batasan jarak dan waktu. Peningkatan interaksi ini lah yang kemudian memberikan kontribusi atas terciptanya situasi saling ketergantungan antar bangsa.

Seiring dengan peran globalisasi sebagai roda penggerak era kontemporer, kajian hubungan internasional pun mau tidak mau akan turut mengikuti pola perkembangan era ini. Sebagai salah satu konsep yang menjadi karakteristik dari kajian hubungan internasional, diplomasi pun dihadapkan pada sejumlah tantangan baru yang menuntutnya untuk mengikuti pola perkembangan era kontemporer. Jika dilihat dari kaca mata diplomasi, globalisasi memicu tumbuhnya dua kondisi baru yang kerap kali menjadi sorotan dalam kajian hubungan internasional, yaitu munculnya aktor bukan negara dan meluasnya ragam isu. Dengan adanya kedua kondisi demikian, tantangan bagi diplomasi untuk mempertahankan eksistensinya pun semakin tak terelakkan. Penelitian ini memuat alur pemikiran tentang bagaimana kedua kondisi yang diakibatkan oleh globalisasi tersebut dapat memunculkan tantangan bagi diplomasi beserta contoh kasus yang dapat mewakilinya. 


\section{Kajian Pustaka}

Diplomasi merupakan salah satu instrumen penting dalam pelaksanaan kepentingan nasional suatu negara. Diplomasi bagaikan alat utama dalam pencapaian kepentingan nasional yang berkaitan dengan negara lain atau organisasi internasional. Melalui diplomasi ini lah sebuah negara dapat membangun citra tentang dirinya. Dalam hubungan antar negara, pada umumnya diplomasi diterapkan sejak tingkat paling awal sebuah negara hendak melakukan hubungan bilateral dengan negara lain hingga keduanya mengembangkan hubungan selanjutnya.

Menurut G.R. Berridge (2010), konsep diplomasi merujuk pada aktivitas politik yang dilakukan oleh para aktor untuk mengejar tujuannya dan mempertahankan kepentingannya melalui negosiasi, tanpa menggunakan kekerasan, propaganda, atau hukum. Diplomasi terdiri dari komunikasi antar sejumlah pihak yang didesain untuk mencapai kesepakatan. Sedangkan menurut KM Panikkar (1956), diplomasi, dalam hubungannya dengan politik internasional, adalah seni mengedepankan kepentingan suatu negara dalam hubungannya dengan negara lain (Roy 1991, 2-3). Pendapat yang berbeda dikemukakan oleh Sir Earnest Satow (1957) yang mengartikan diplomasi sebagai penerapan kepandaian dan taktik pada pelaksanaan hubungan resmi antar pemerintah negara-negara berdaulat.

Tidak jauh berbeda dengan konsep diplomasi, konsep globalisasi pun ditafsirkan secara berbeda-beda oleh para pengamat. Beberapa di antaranya adalah Robert Keohane dan Joseph Nye (2000) yang menyatakan bahwa globalisasi adalah turunan dari globalisme. Globalisme itu sendiri merujuk pada situasi dunia yang melibatkan jaringan-jaringan interdependensi atau saling ketergantungan pada jarak yang membentang luas. Jika globalisme mengalami peningkatan, maka yang terjadi adalah globalisasi. Sebaliknya, jika globalisme mengalami penurunan, maka yang terjadi adalah deglobalisasi. Keohane dan Nye (2000) menggambarkan kondisi saling ketergantungan tersebut dalam lima bidang, yaitu ekonomi, budaya, masyarakat, lingkungan, dan militer. Globalisasi secara abstrak juga dirumuskan sebagai proses ketika masyarakat di dunia bergabung dalam sebuah masyarakat dunia tunggal, yaitu global society (Allbrow and King. eds 1990) dan sebagai intensifikasi hubungan sosial berskala dunia yang memungkinkan keterkaitan masyarakat lokal dengan kejadiankejadian di bagian-bagian dunia lainnya atau sebaliknya (Giddens 1990). 
Beberapa orang menganggap bahwa globalisasi terjadi di tahun 1990-an, yaitu ditandai dengan berakhirnya Perang Dingin. Namun, awal mula dari munculnya globalisasi sebenarnya bukan dimulai di tahun 1990-an, tetapi bahkan jauh sebelum tahun tersebut, globalisasi telah ada. Dalam sejarahnya, gelombang globalisasi terbagi ke dalam tiga periode.

Pertama, globalisasi pada periode sebelum tahun 1600-an, atau yang disebut sebagai Archaic Globalization. Pada periode ini, globalisasi terjadi ketika ada interaksi antara penduduk di wilayah suatu negara dengan penduduk di wilayah negara lain. Interaksi ini terjadi karena penduduk di negara yang berbeda tersebut saling melakukan perdagangan, yaitu dengan adanya jual beli barang mewah dan antik. Aktivitas perdagangan tersebut membuat para pedagang di berbagai negara saling menyadari kehadiran mereka satu sama lain. Aktivitas perdagangan ini juga lah yang membuat barang dan budaya menyebar di luar batas negara asalnya. Saling ketergantungan pun pada akhirnya tercipta di antara mereka. Ciri khas dari Archaic Globalization adalah penggunaan Jalur Sutera. Jalur Sutera adalah jalur perdagangan yang dilewati ketika kerajaan Roma dan Cina saling melakukan jual beli barang. Jalur ini membentang dari benua Eropa ke dataran Cina.

Kedua, globalisasi pada periode tahun 1600-1800, atau yang disebut sebagai Proto-Globalization. Pada periode ini, hubungan perdagangan di antara negaranegara semakin meningkat, diikuti dengan meningkatnya pertukaran budaya secara lintas negara. Ekspansi negara-negara besar untuk menguasai negara lain pun mulai marak terjadi. Ciri dari Proto-Globalization adalah terbentuknya kesepatakan perdagangan antara negara yang satu dengan negara yang lain, salah satunya yaitu East India Company yang merupakan kesepakatan perdagangan antara Inggris dengan India.

Ketiga, globalisasi pada periode tahun 1800-sekarang, atau yang disebut sebagai Modern Globalization. Globalisasi di periode ini lah yang banyak dikenal oleh masyarakat luas. Pada periode ini, banyak ditemukan teknologi baru yang sangat berperan penting dalam memfasilitasi interaksi antar individu termasuk penggunaan internet yang semakin menyebar ke masyarakat luas, dari anak-anak hingga para orang tua sekalipun. Kemajuan teknologi pun pada akhirnya semakin membuat ruang dan waktu terasa semakin menyempit, Oleh karena itu, kemajuan teknologi informasi dan 
komunikasi atau Information and Communication Technology (ICT) menjadi ciri khas dari Modern Globalization.

Sementara itu, Jan Aart Scholte (2000), seorang peneliti globalisasi, mengemukakan bahwa konsep dasar globalisasi menggambarkan lima macam fenomena. Pertama, internasionalisasi, yaitu meningkatnya intensitas interaksi lintas batas dan saling ketergantungan antar negara. Kedua, liberalisasi, yaitu pengurangan hambatan-hambatan perdagangan hingga membuat perekonomian dunia menjadi lebih terintegrasi. Ketiga, universalisasi, yaitu menyebarnya berbagai macam obyek dan pengalaman dari masyarakat di seluruh dunia. Keempat, westernisasi, yaitu kritik terhadap proses yang sedang berjalan sebagai proses peniruan budaya Barat atau bahkan proses memaksakan sistem budaya, sistem politik, dan sistem ekonomi negaranegara Barat dalam panggung dunia.

Secara garis besar, terdapat empat karakteristik dasar dari globalisasi (Hermawan.ed 2007). Pertama, meluasnya hubungan sosial, yang berarti adanya saling keterhubungan antara jaringan sosial-budaya, ekonomi, dan politik di masyarakat yang melintasi batas negara bangsa. Kedua, meningkatnya intensitas komunikasi, yaitu berkaitan dengan makin meningkatnya intensitas hubungan antar aktor dengan munculnya perkembangan ilmu dan teknologi. Ketiga, meningkatnya interpenetrasi di hampir segala bidang, yang kemudian mengakibatkan budaya dan masyarakat yang berada di wilayah berbeda akan saling berhadapan pada level lokal dan internasional. Keempat, munculnya infrastruktur global, yang merujuk pada dibutuhkannya pengaturan institusional yang bersifat formal dan informal agar jaringan global bekerja.

\section{Metode Penelitian}

Untuk menjawab rumusan masalah dalam penelitian ini, penulis melakukan pengumpulan data melalui studi dokumentasi, yang berarti bahwa data yang akan digunakan penulis dalam hal ini adalah data sekunder. Dengan kata lain, penulis bertindak sebagai tangan kedua karena menggunakan data yang diperoleh dari berbagai sumber yang ada seperti buku, jurnal, dan artikel online, yang selanjutnya dilakukan proses analisa dan interpretasi terhadap data-data tersebut sesuai dengan tujuan penelitian. Terkait dengan proses analisa, penulis dalam hal ini melakukan analisa data secara kualitatif, yaitu setelah fakta dan data yang mendukung penelitian ini ditemukan 
melalui sumber-sumber yang dapat dipercaya, maka selanjutnya penulis akan menghubungkannya dengan konsep yang relevan, untuk kemudian diambil kesimpulan berdasarkan relevansi dari konsep tersebut. Selain itu, mengingat bahwa penelitian ini bersifat menggeneralisasi obyek penelitian, yaitu praktek diplomasi di era kontemporer, maka lokasi dan jangka waktu penelitian pun berada pada tataran hubungan internasional secara keseluruhan dari waktu ke waktu.

\section{Hasil dan Pembahasan}

\section{Globalisasi Menyebabkan Munculnya Aktor-Aktor Baru dan Perkembangan Isu}

Inti dari globalisasi itu sendiri pada dasarnya terletak ketika negara memutuskan untuk membuka batas-batas teritorialnya terhadap arus barang, modal, ide, dan manusia, serta perubahan teknologi yang memfasilitasi pesatnya arus lintas batas tersebut (http://uspublicdiplomacy.org, diakses 10 Januari 2014). Selain kemajuan nyata yang nampak dari perkembangan teknologi transportasi, revolusi dalam teknologi informasi dan komunikasi pun turut memperdalam adanya integrasi global.

Dalam konteks hubungan internasional, arus globalisasi mengakibatkan munculnya aktor-aktor baru seiring dengan isu-isu internasional yang juga berkembang. Hal ini dikemukakan oleh Alatas (dalam Rochmadi 2008) yang menggambarkan sejumlah kecenderungan mutakhir dalam hubungan internasional. Menurutnya, ada empat perubahan mendasar terkait dengan permasalahan di atas yang mempunyai pengaruh sangat besar dalam hubungan antar bangsa. Pertama, kecenderungan ke arah perubahan dalam konstelasi politik global, dari suatu kerangka bi-polar ke kerangka multi-polar. Kedua, menguatnya gejala saling ketergantungan antar negara dan saling keterkaitan antar masalah global di berbagai bidang meliputi politik, keamanan, ekonomi, sosial, lingkungan hidup, dan sebagainya. Seiringan dengan hal itu, semakin menguat pula dampak globalisasi dengan segala implikasinya, baik yang positif maupun yang negative. Ketiga, meningkatnya peranan aktor-aktor nonpemerintah dalam tata hubungan antar negara. Keempat, munculnya isu-isu baru dalam agenda internasional seperti masalah hak asasi manusia, intervensi humaniter, demokrasi dan demokratisasi, good governance, lingkungan hidup, dan sebagainya. 
Munculnya aktor baru merupakan hasil dari adanya perubahan politik dalam hubungan internasional sebagai akibat dari eksistensi keempat karakteristik dasar yang dimiliki oleh globalisasi sebagaimana yang telah dikemukakan oleh Hermawan. ed (2007). Jika dijabarkan, dampak keempat karakteristik dasar dari globalisasi tersebut di atas terhadap perubahan politik dapat meliputi tiga hal. Pertama, rekonstruksi negara, yaitu bahwa negara kehilangan kedaulatannya dalam pengertian kedaulatan yang mutlak. Kedua, makin banyaknya lapisan dalam pemerintah publik, yang memunculkan makin banyak aktor dalam pemerintahan. Ketiga, privatisasi pemerintahan, yang dalam hal ini terjadi penguatan peran dari agen-agen seperti kelompok masyarakat sipil atau organisasi non-pemerintah dalam persoalan kebijakan.

Sebagai dampak dari ketiga perubahan politik yang demikian, maka definisi terbaru tentang hubungan internasional kini mengindikasikan perluasan aktor hubungan internasional. Aktor dalam hal ini merujuk pada pelaku dalam interaksi internasional. Dengan adanya perluasan aktor, maka aktor hubungan internasional kini dikelompokkan menjadi dua bagian, yaitu aktor negara dan aktor bukan negara atau aktor non-pemerintah. Jika aktor negara, maka yang menjadi aktor adalah negara secara utuh, yaitu negara berdaulat yang dibangun oleh kesadaran kebangsaan sehigga dapat juga disebut juga sebagai negara bangsa atau nation state, misalnya adalah Indonesia, Amerika Serikat, Australia, Timor Leste, dan sebagainya. Aktor negara ini berbedabeda sistem politiknya. Pada umumnya mereka mengarah kepada negara demokratis, di mana politik pemerintahnya merupakan representasi dari kemauan rakyatnya. Akan tetapi, banyak juga negara yang dikuasai elit pemerintah dan pengusaha, sehingga seolah lepas dari gambaran politik warganya. Sistem politik dalam negeri ini berpengaruh kuat terhadap karakteristik hubungan internasional.

Aktor bukan negara dapat berupa berbagai macam hal. Salah satunya adalah perusahaan multinasional atau Multinational Corporation (MNC). MNC adalah perusahaan yang bergerak hampir di seluruh negara di dunia. Misalnya yaitu perusahaan Coca Cola yang kantor pusatnya terletak di Amerika Serikat, tetapi kantor cabangnya terletak di banyak negara termasuk Indonesia. Selain MNC, aktor lain juga dapat berupa organisasi pemerintah internasional atau International Governmental Organization (IGO). IGO adalah organisasi internasional yang anggotanya terdiri dari negara atau pemerintah. IGO dapat berskala regional maupun global. IGO yang berskala regional 
contohnya adalah ASEAN dan EU, sedangkan yang berskala global contohnya adalah PBB. Aktor yang bertema organisasi internasional juga dapat berupa organisasi nonpemerintah atau International Governmental Organization (NGO). Bertolak belakang dengan IGO, anggota dalam NGO ini justru adalah bukan negara maupun pemerintah karena NGO merupakan organisasi non-profit berskala internasional yang biasanya memperjuangkan nilai-nilai kemanusiaan dan lingkungan hidup. Beberapa contoh dari NGO adalah Green Peace, World Wild Foundation, dan sebagainya.

Kejahatan transnasional terorganisir atau Transnational Organized Crime (TOC) adalah aktor lainnya yang juga merupakan aktor bukan negara karena pengaruhnya yang signifikan terhadap interaksi antar negara. Salah satunya adalah Yakuza yang merupakan kejahatan terorganisasi asal Jepang. Yakuza membuka jaringannya di Amerika Serikat dan negara lain, bukan hanya untuk peredaran narkotika, tetapi juga uang palsu dan perdagangan manusia. Selain Yakuza ada juga aksi terorisme yang dilakukan oleh kelompok bernama Al Qaeda. Mereka mengembangkan jaringan terorisme di sejumlah negara hingga menimbulkan ancaman keamanan internasional.

Sedangkan terkait dengan perkembangan isu, pada dasarnya ada dua hal yang dapat menjadi penjelasan mengapa isu-isu internasional dapat berkembang. Pertama, adanya peningkatan interaksi antar masyarakat yang memicu potensi terjadinya konflik dengan kepentingan yang berbeda-beda. Kedua, kaburnya batasbatas antar negara yang turut mengkaburkan batas-batas antara isu domestik dengan isu internasional. Kedua hal ini tidak terlepas dari peran globalisasi dalam membentuk global society sebagaimana yang diungkapkan oleh Allbrow dan King. eds (1990) dan dalam menciptakan intensifikasi hubungan sosial berskala dunia sebagaimana yang diungkapkan oleh Giddens (1990).

Munculnya isu baru dalam hubungan internasional merupakan akibat dari adanya broadening dan deepening pada isu sebagai salah satu pengaruh yang ditimbulkan oleh globalisasi. Broadening merujuk pada perluasan aspek dari isu, dari yang sebelumnya cenderung merupakan isu-isu high politics yang meliputi isu-isu keamanan dan kekuasaan, sekarang meluas menjadi isu-isu low politics yang meliputi isu-isu seperti isu pangan, lingkungan, kemanusiaan, dan sebagainya. Sedangkan deepening lebih merujuk pada spesifikasi obyek atau sasaran dari isu, dari yang sebelumnya cenderung isu-isu 
yang menyangkut persoalan kenegaraan, sekarang menjadi isu-isu yang dapat menyangkut siapa saja, termasuk perorangan, bumi, hewan, dan sebagainya. Perluasan isu-isu ini mengindikasikan bahwa hubungan internasional kini tidak hanya menyangkut interaksi antar negara, tetapi juga interaksi siapa pun, kapan pun, dan dimana pun.

\section{Kemunculan Aktor Baru dan Perkembangan Isu Mempengaruhi Perkembangan Diplomasi}

Berdasarkan pengertian dari diplomasi sebagaimana yang dikemukakan G.R. Berridge (2010) bahwa konsep diplomasi merujuk pada aktivitas politik yang dilakukan oleh para aktor untuk mengejar tujuannya dan mempertahankan kepentingannya, maka dalam hal ini akan terlihat bahwa diplomasi cenderung bersifat dinamis karena disesuaikan dengan bagaimana aktor tersebut akan menggunakan diplomasi nantinya. Sebagai dampaknya, perkembangan pada diplomasi pun bisa saja terjadi.

Munculnya aktor-aktor baru beserta isu-isu yang berkembang akibat globalisasi, secara otomatis berdampak pada perkembangan diplomasi di era kontemporer. Sebagai respon atas munculnya aktor-aktor baru dalam isu-isu internasional, praktek diplomasi mengalami perluasan dari sisi aktivitas diplomasi yang sekarang menjadi lebih fleksibel karena dapat dilakukan oleh siapa pun, di mana pun, dan dalam bentuk apapun. Multi-track diplomacy adalah wujud dari perkembangan diplomasi dari sisi ini. Sedangkan untuk respon atas isu-isu yang berkembang, praktek diplomasi kini dilakukan dengan cara-cara yang lebih bervariatif dibandingkan sebelumnya. Isu-isu seperti perdagangan, keuangan, migrasi, hak asasi manusia, dan lingkungan, menjadi isu-isu yang tidak cukup diselesaikan hanya dengan menggunakan hard power. Hal inilah yang kemudian mendorong munculnya kreativitas dalam praktek diplomasi.

Salah satu bentuk kreativitas praktek diplomasi yang kini banyak digunakan oleh negara-negara adalah dengan memanfaatkan kemajuan teknologi informasi dan komunikasi seperti surat elektronik, media sosial, dan sebagainya. Perkembangan teknologi tersebut diyakini dapat mempengaruhi penyebaran akses informasi yang lebih luas dan cepat. Dengan begitu, praktek diplomasi dengan 
perantara media akan membuat kinerja diplomasi menjadi lebih efektif. Bentuk kreativitas lainnya dalam praktek diplomasi dapat ditemukan dari beragamnya konsep diplomasi yang berkembang. Beberapa di antaranya adalah diplomasi panda, yaitu diplomasi yang dilakukan Cina ke Amerika Serikat dengan memberikan panda; diplomasi pingpong, yaitu diplomasi yang dilakukan dengan cara mempertukarkan pemain tenis dari kedua negara; diplomasi publik, yaitu diplomasi yang dilakukan dengan cara mempengaruhi masyarakat dari negara yang menjadi sasaran diplomasi dengan memanfaatkan budaya, pariwisata, kuliner, dan sebagainya; diplomasi dollar, yaitu diplomasi yang dilakukan dengan cara memberikan bantuan; serta masih banyak lagi bentuk-bentuk diplomasi yang dapat dikembangkan di era kontemporer ini. Perkembangan tipe diplomasi ini mengindikasikan bahwa praktek diplomasi kini tidak lagi identik dengan pertemuan atau perundingan yang dilakukan antar negara sebagaimana diplomasi yang berkembang di era tradisional.

\section{Perkembangan Diplomasi Mengakibatkan Adanya Changing Nature of Diplomacy}

Perkembangan yang dialami oleh praktek diplomasi di era kontemporer pada akhirnya mengarahkan kepada adanya changing nature of diplomacy. Dalam changing nature of diplomacy, perkembangan praktek diplomasi berakibat pada sejumlah kondisi berikut (Tariqul Islam 2005). Pertama, berkurangnya peran diplomat dalam mengambil keputusan. Hal ini terjadi karena peran diplomat mulai tergantikan oleh kehadiran teknologi yang mempermudah aktivitas diplomasi untuk dapat dilakukan dengan lebih efektif tanpa harus mengirim seorang diplomat sebagai perwakilan negara. Kedua, intensitas diplomasi bilateral mengalami penurunan. Aktor-aktor baru mulai bermunculan, mereka memiliki kepentingan masing-masing, dan melakukan diplomasi dalam bentuk yang berbeda-beda. Kemunculan para aktor baru tersebut kemudian mendorong dominasi diplomasi multilateral dalam hubungan internasional sebagai akibat atas lahirnya organisasi-organisasi internasional. Ketiga, meredupnya eksistensi institusi diplomatik yang berperan dalam membantu terjadinya hubungan diplomatik dan memfasilitasi hubungan diplomatik melalui aturan dan perjanjian. Hal ini terjadi karena peran institusi diplomatik tesebut sudah tidak begitu dibutuhkan dengan pertimbangan bahwa praktek diplomasi kini dapat dilakukan melalui beragam cara. 


\section{Changing Nature of Diplomacy Memunculkan Tantangan Baru Bagi Diplomasi}

Akibat adanya changing nature of diplomacy, diplomasi di era kontemporer pun kemudian dihadapkan pada sejumlah tantangan. Tantangan tersebut tidak lain adalah bagaimana diplomasi merespon kompleksitas isu jika diplomasi dihadapkan pada situasi ketika peran diplomat tergantikan oleh teknologi, ketika aktivitas diplomasi bilateral mulai berkurang, serta ketika keberadaan institusi diplomatik mulai tenggelam. Hal inilah yang membuat para aktor diplomasi dituntut untuk berpikir secara lebih kreatif dan membuka wawasan lebih luas untuk menemukan cara penyelesaian yang strategis disesuaikan dengan isu yang dihadapi.

Ketika hard power sudah tidak lagi mampu menyelesaikan suatu isu internasional, maka yang dibutuhkan adalah cara yang dapat menarik perhatian agar mengundang respon positif dari pihak lain. Untuk menarik perhatian agar pihak lain memberikan respon positif, para aktor diplomasi dituntut untuk mengembangkan kreativitas penggunaan soft power. Salah satu caranya adalah dengan menarik minat kerja sama melalui unjuk kekuatan. Misalnya saja ketika negara A mengetahui potensi yang dimiliki oleh negara B, maka ketika negara B menawarkan kerja sama, besar kemungkinan bagi negara A untuk menerima tawaran kerja sama tersebut karena tertarik dengan potensi yang dimiliki oleh negara B. Kerja sama inilah yang nantinya akan menjadi perpanjangan tangan bagi negara B untuk mencapai kepentingan nasionalnya di negara A. Banyaknya kerja sama ekonomi yang mengatasnamakan perdagangan bebas, seperti ASEAN-China Free Trade Area (ACFTA), North American Free Trade Area (NAFTA), dan sebagainya adalah salah satu perwujudan praktek diplomasi dari segi ini.

Cara lain yang dapat dilakukan adalah dengan membangun opini publik di mata masyarakat internasional. Opini publik dibutuhkan untuk menggalang dukungan bagi eksistensi aktor dalam suatu isu internasional yang tengah berkembang. Pada umumnya, pembangunan opini publik dilakukan dengan bantuan media karena media berperan dalam mempublikasikan segala hal yang berhubungan dengan para aktor diplomasi serta isu-isu internasional yang tengah memanas. Keberadaan media tersebut kemudian akan memberikan efek yang baik bagi para aktor diplomasi dengan adanya pemberitaan tentang tindakan-tindakan positif yang dilakukan oleh para aktor, hingga 
pada akhirnya akan menarik perhatian masyarakat internasional. Akan tetapi, di sisi lain, media juga dapat memberikan efek buruk ketika tindakan-tindakan negatif para aktor disoroti, yang pada akhirnya berdampak pada citra negaranya di mata masyarakat internasional. Oleh karena itulah maka para aktor diplomasi diharuskan untuk berhatihati dalam bertindak di manapun ia berada.

\section{Contoh Kasus: Peran USAID terhadap Ekspansi Multinational Corporation (MNC) Sektor Migas Asal Amerika Serikat di Indonesia}

USAID merupakan lembaga independen yang berada di bawah Departemen Luar negeri AS dan memiliki program untuk memberikan bantuan bagi negara-negara dunia ketiga. Posisi USAID sendiri dalam politik luar negeri AS adalah sebagai agen utama pemerintah AS dalam memberikan bantuan ekonomi dan kemanusiaan pada negara-negara berkembang. Bantuan luar negeri yang dikeluarkan oleh USAID akan selalu sejalan dengan kepentingan AS, seperti meningkatkan angka pertumbuhan ekonomi AS, mempromosikan perdagangan bebas, dan sebagainya.

Dalam kaitannya dengan Indonesia, salah satu kepentingan AS dalam memberikan program USAID bagi Indonesia adalah agar peraturan undang-undang untuk sektor migas yang berlaku di Indonesia dapat sejalan dengan kepentingan MNC sektor migas asal AS. Mengingat banyaknya MNC sektor migas asal AS yang beroperasi di Indonesia, maka AS pun berharap bahwa peraturan undang-undang untuk sektor migas yang diberlakukan di Indonesia tidak akan menyulitkan MNC dalam melakukan ekspansi bisnisnya. Kepentingan tersebut berangkat dari hubungan antara pemerintah AS dengan sejumlah MNC sektor migas di negaranya yang secara umum dapat digambarkan sebagai hubungan yang saling menguntungkan. Pemerintah AS membutuhkan MNC untuk memenuhi kebutuhan energi di dalam negeri, sementara MNC membutuhkan peran pemerintah AS untuk membantu meningkatkan eksplorasi dan eksploitasi bisnis migasnya di sejumlah negara, termasuk Indonesia. Oleh karena itu, sangatlah wajar jika pemerintah AS selalu mengeluarkan kebijakan yang bertujuan untuk melindungi para MNC-nya.

Peran USAID dalam mencapai kepentingan AS untuk sektor migas adalah ketika USAID berhasil mempengaruhi pemerintah Indonesia untuk meliberalisasi sektor migas. Liberalisasi sektor migas nampak dari adanya perubahan Undang- 
Undang No 8 Tahun 1971 menjadi Undang-Undang No 22 Tahun 2001. UndangUndang No 8 tahun 1971 bersifat menjamin kepentingan nasional Indonesia karena dalam UU tersebut pengelolaan sektor hulu dan hilir migas tidak dipisahkan mengingat migas sebagai kebutuhan yang sangat vital dan menguasai hajat hidup orang banyak. UU ini juga ditujukan untuk menjaga stabilitas harga dan pemenuhan pasokan sumber energi bagi masyarakat. Sedangkan Undang-Undang No 22 Tahun 2001 dirancang untuk membuka dan meliberalisasi sektor migas di Indonesia. Secara umum, UU ini mengandung empat agenda utama (http:/ / suma.ui.ac.id, diakses 12 Januari 2014), yaitu (1) mengakhiri kedudukan Pertamina sebagai pemegang Kuasa Pertambangan; (2) mengakhiri Pertamina sebagai pemegang monopoli atas penyelenggaraan sektor hilir migas serta memecah Pertamina menjadi beberapa ranting perusahaan dengan badan hukum tersendiri; (3) menghapus subsidi BBM secara bertahap untuk akhirnya menyerahkan harga BBM kepada mekanisme pasar; dan (4) membuka peluang bagi badan usaha swasta, baik domestik maupun asing, untuk bergerak di sektor hulu dan hilir migas.

Keempat agenda utama tersebut di atas merupakan hasil dari pengaruh yang diberikan oleh USAID kepada pemerintah Indonesia, yang pada akhirnya mendorong pemerintah Indonesia untuk mengubah UU migasnya. Pengaruh USAID sebagaimana dimaksud dalam hal ini dapat dijumpai pada policy papenya yang berjudul Energy and Sector Governance Stengthened, 497-013. Sebagian dari isi policy paper tersebut berhubungan dengan bentuk-bentuk intervensi USAID.

Dalam poin pertama, USAID menyebutkan bahwa dengan meminimalisir peran pemerintah sebagai regulator di bidang migas, mengurangi subsidi kepada masyarakat, serta mereformasi sektor energi akan menghasilkan miliaran dollar setoran pajak. USAID menekankan bahwa dengan lebih mengefisiensikan sektor energi akan memberikan dampak positif terhadap lingkungan, membuat harga sumber energi menjadi lebih rasional, meningkatkan akses terhadap pelayanan energi, dan membantu menopang SDA yang dimiliki Indonesia. USAID juga menegaskan bahwa ia adalah lembaga bilateral yang menjadi aktor utama dalam proses reformasi sektor energi di Indonesia, dengan dibantu oleh beberapa lembaga donor lainnya.

Dalam poin kedua, USAID menyatakan akan membantu pemerintah Indonesia agar parlemen, LSM, media, dan universitas dilibatkan dalam program 
penghapusan subsidi, sehingga penghapusan subsidi tidak akan menimbulkan reaksi yang berlebihan dari masyarakat. Adanya peran USAID dalam membantu pemerintah Indonesia ini terlihat dari pernyataan Kepala BAPPENAS pada waktu itu, yaitu Paskah Suzetta, yang menyarankan agar subsidi energi dicabut secara bertahap. Paskah juga menyarankan agar harga minyak dinaikkan sebesar 2\% setiap bulan selama setahun sehingga harga minyak nantinya akan sesuai dengan harga pasar (Nizami 2008).

Berdasarkan pemaparan tersebut di atas, dapat disimpulkan bahwa peran USAID terhadap pemerintah AS dinilai sangat siginifikan karena telah berhasil mendorong ekspansi bisnis MNC sektor migas asal AS melalui adanya perubahan UU migas di Indonesia. Dengan demikian, upaya pemerintah AS dalam mengeksploitasi sumber daya migas di Indonesia melalui para MNC-nya pun akan menjadi semakin mudah.

Terkait kasus USAID ini, upaya diplomasi yang nampak jelas adalah ketika pemerintah AS mengatasnamakan USAID untuk menjalin hubungan dengan Indonesia. Namun dalam analisa penulis, sebenarnya praktek diplomasi dalam kasus tersebut dilakukan secara berantai karena USAID ditujukan untuk mendukung kelancaran bisnis $\mathrm{MNC}$, sementara $\mathrm{MNC}$ tersebut kemudian akan dijadikan sebagai perpanjangan tangan pemerintah AS dalam mendongkrak kepentingan perekonomian negaranya. Ini adalah bentuk bagaimana AS merespon tantangan diplomasi dengan menggunakan soft power yang lebih kreatif dalam aktivitas diplomasinya.

Pemerintah AS menggunakan USAID untuk menarik perhatian Indonesia akan pentingnya bantuan pembangunan yang dibutuhkan oleh Indonesia. Selain untuk mendorong kerja sama, keberadaan USAID juga ditujukan untuk membangun citra positif AS di mata masyarakat Indonesia. Sedangkan kegigihan pemerintah AS dalam menopang ekspansi bisnis MNC adalah untuk mewujudkan kepentingan AS dalam menguasai sumber-sumber energi yang secara tidak langsung didapatkannya melalui ekspansi bisnis MNC tersebut. Dengan demikian, diplomasi AS terhadap Indonesia dilakukan secara tidak langsung melalui peran aktor-aktor diplomasi, yaitu MNC sebagai track 3 (bisnis) dan USAID sebagai track 8 (pendanaan). Hal inilah yang mencerminkan munculnya aktor-aktor baru dalam diplomasi kontemporer. 


\section{Kesimpulan}

Keterkaitan antara globalisasi dengan diplomasi di era kontemporer membentuk suatu mata rantai. Dalam konteks hubungan internasional, arus globalisasi mengakibatkan munculnya aktor-aktor baru seiring dengan isu-isu internasional yang juga berkembang. Kedua hal tersebut kemudian mempengaruhi perkembangan diplomasi, hingga berdampak pada adanya changing nature of diplomacy. Dengan adanya changing nature of diplomacy inilah sejumlah tantangan baru pun muncul. Secara sederhana, dapat dikatakan bahwa inti dari tantangan diplomasi di era kontemporer ini adalah upaya aktor diplomasi dalam melakukan tindakan atau pernyataan persuasif yang dapat mempengaruhi kehendak pihak lain. Upaya ini berkaitan dengan pengembangan kreativitas dalam penggunaan soft power karena hard power dipandang sudah tidak lagi kompatibel untuk beberapa isu yang telah mengalami perkembangan.

\section{Daftar Rujukan}

\section{Buku}

Allbrow, M. \& Elizabeth K. (eds). (1990). Globalization Knowledge and Society. London: Sage Publication.

Berridge, G. R. (2010). Diplomacy: Theory and Practice, $2^{\text {nd }}$ ed. New York: Palgrave Giddens, A.. (1990). The Consequences of Modernity. Stanford: Stanford University Press. Hermawan, Y. P. (Ed.). (2007). Transformasi dalam Studi Hubungan Internasional: Aktor, Isu, dan Metodologi. Yogyakarta: Graha Ilmu.

Panikkar, K. M. (1956). The Principle and Practice of Diplomacy. Asia Publishing House.

Perwita, A. A. B. dan Yani, Y. M. (2006). Pengantar Ilmu Hubungan Internasional. Bandung: Remaja Rosdakarya

Rochmadi, N. W. (2008). Hubungan dan Organisasi Internasional. Malang: P4TK PKn dan IPS.

Roy, S. L. (1991). Diplomasi. Jakarta: PT. Raja Grafindo.

Scholte, J. A. (2000). Globalization: A Critical Introduction. London: Macmilan.

\section{Jurnal}

Keohane, R. dan Joseph, S. N. (2000). Globalization: What's New? What's Not (And so What?), Foreign Policy, 118. 
Nizami, A. (2008). USAID Buat Draft UU Migas Tahun 2000: Indonesia Dijajah AS?, Suara Merdeka, 25 Juni.

Tariqul, I. S. M. (2005). "Changing Nature and Agenda of Diplomacy: A Critical Analysis", dalam Asian Affairs, Vol.27, No.1. CDRB Publication.

\section{Artikel Online}

Starr, P. K. (n.d.). "Globalization, Interdependency, and Public Diplomacy.” Diakses 10 Januari 2014, pada http://uscpublicdiplomacy.org/index.php/pdin_monitor/article/globali zation_interdependency_and_public_diplomacy/

Suara Mahasiswa. (2012). Kebijakan Migas di Indonesia: Milik Bangsa atau Asing? Diakses 12 Januari 2014, pada http://suma.ui.ac.id/2012/01/26/kebijakan-migas-di-indonesia-milikbangsa-atau-asing/ 